\title{
Original Paper \\ Rhytismataceae in leaf litter of the Atlantic Forest in Southern Bahia, Brazil ${ }^{1}$
}

\author{
Marcos Vinícius Oliveira dos Santos ${ }^{2,6,7}$, Flávia Rodrigues Barbosa ${ }^{3}$, Edna Dora Martins Newman Luz ${ }^{2}$, \\ Nadja Santos Vitória ${ }^{4}$, Irina Zélia Vieira Lessa ${ }^{2} \&$ José Luiz Bezerra ${ }^{5}$
}

\begin{abstract}
The order Rhytismatales consists of four families (Ascodichaenaceae, Cryptomycetaceae, Cudoniaceae, and Rhytismataceae) and includes saprobes, necrotrophic parasites, and endophytic ascomycetes. Rhytismatales has a wide geographical distribution but has not been well studied in some regions of the world. The present study aimed to identify ascomycetes of the family Rhytismataceae in leaf litter of representative plants of the Atlantic Forest biome at the Biological Reserve in the municipality of Una (Reserva Biológica do Município de Una; REBIO-Una) in Bahia, Brazil. Samples of Inga thibaudiana, Myrcia splendens, and Pera glabrata leaf litter were collected at REBIO-Una in September 2011, April and August 2012, and January 2013 and incubated in a moist chamber. The fungal species were identified using morphological criteria. Three species belonging to the family Rhytismataceae were identified: Coccomyces leptosporus (associated with $I$. thibaudiana leaf litter), Marthamyces quadrifidus (on M. splendens and P. glabrata leaf litter), and Terriera javanica (associated with $M$. splendens leaf litter). This is the first record of T. javanica in the Americas, $M$. quadrifidus in the Brazilian Northeast, and C. leptosporus in southern Bahia.
\end{abstract}

Key words: Ascomycota, Fabaceae, Myrtaceae, Peraceae, taxonomy.

\section{Resumo}

A ordem Rhytismatales possui quatro famílias (Ascodichaenaceae, Cryptomycetaceae, Cudoniaceae e Rhytismataceae) e é representada por ascomicetos sapróbios, parasitas necrotróficos e endofíticos. Tem ampla distribuição geográfica, porém tem sido pouco estudada em algumas localidades do globo terrestre. O presente trabalho teve como objetivo identificar ascomicetos da família Rhytismataceae em folhedo de plantas representativas do bioma Mata Atlântica na Reserva Biológica do Município de Una (REBIO-Una), Bahia, Brasil. Amostras de folhedo de Inga thibaudiana, Myrcia splendens e Pera glabrata foram coletadas na REBIO-Una em setembro/2011, abril e agosto/2012 e janeiro/2013 e incubadas em câmara úmida. As espécies fúngicas foram identificadas por critérios morfológicos. Três espécies, pertencentes à família Rhytismataceae, foram identificadas: Coccomyces leptosporus (associada ao folhedo de I. thibaudiana), Marthamyces quadrifidus (presente no folhedo de M. splendens e P. glabrata), e Terriera javanica (associada ao folhedo de M. splendens). Este é o primeiro relato de T. javanica para as Américas, de M. quadrifidus para o nordeste brasileiro e de C. leptosporus para a região sul da Bahia.

Palavras-chave: Ascomycota, Fabaceae, Myrtaceae, Peraceae, taxonomia.

\footnotetext{
${ }^{1}$ Part of the Doctoral thesis of the first author.

${ }^{2}$ Centro de Pesquisas do Cacau, Comissão Executiva do Plano da Lavoura Cacaueira, Setor de Fitopatologia, Rod. Ilhéus-Itabuna, km 22, 45662-000, Ilhéus, BA, Brazil.

${ }^{3}$ Universidade Federal de Mato Grosso, Inst. Ciências Naturais, Humanas e Sociais, Av. Alexandre Ferronato 1200, Setor Industrial, 78557-267, Sinop, MT, Brazil.

${ }^{4}$ Universidade do Estado da Bahia, Depto. Educação, R. do Gangorra 503, Bairro Alves de Souza, 48608-240, Paulo Afonso, BA, Brazil.

${ }^{5}$ Universidade Federal de Pernambuco, Depto. Micologia, Av. Prof. Nelson Chaves s/n, 50670-901, Recife, PE, Brazil.

${ }^{6}$ ORCID: <https://orcid.org/0000-0002-0506-7461>

${ }^{7}$ Author for correspondence: marcosvos@ymail.com
} 


\section{Introduction}

Rhytismatales is a polyphyletic order that belongs to the class Leotiomycetes (Ascomycota) and encompasses four families: Ascodichaenaceae, Cryptomycetaceae, Cudoniaceae, and Rhytismataceae (Lantz et al. 2011).

Over 700 Rhytismatales species have been described. The order has the following general characteristics: apothecial, submerged ascoma that are sometimes erumpent, opening by radial or longitudinal slits, often within a black, pseudostromatic, clypeated pseudo-tissue; interascal pseudo-tissue consisting of simple paraphyses, often with an anastomosis near the base, a mucous coating, and a tumescent apex; cylindrical, thin-walled asci, usually undifferentiated at the apex, that rarely react with iodine and often release spores through an irregular slit; ascospores, usually hyaline and aseptate, that are frequently elongated with a mucilaginous coating; and the anamorphs are coelomycetes (Kirk et al. 2008).

The spore characteristics and ascoma shape, traditionally used for the taxonomy of the group, are limited in defining the genera and must be used only in combination with other morphological and biological characteristics, such as specificity to the host and geographical distribution (Lantz et al. 2011).

The ascomycetes of the order Rhytismatales are saprobes and necrotrophic parasites and are sometimes endophytic, occurring in leaves, bark, and wood, especially in temperate climates (Kirk et al. 2008).

Rhytismatales specimens are widespread throughout the world, as confirmed by Johnston \& Park (2007), who provided a list and revision of the species described by Spegazzini (1885) in South America, and Hou \& Piepenbring (2009), who describe four new species and present new records for Panamá. Hernández et al. (2014) listed the species identified in Cuba; Chen et al. (2011) and Zheng et al. (2011) recorded the Rhytismatales species present in different plant tissues in China, while, Li et al. (2014) described three new species and found two new reports of Rhytismatales in Japan. However, the number of Rhytismatales species present worldwide is poorly understood. Therefore, more collections are needed, particularly in Africa, Asia, and South and Central America (Lantz et al. 2011).

The objective of this study was to record ascomycetes of the family Rhytismataceae in the leaf litter of representative plants of the Atlantic Forest biome at the Biological Reserve in the municipality of Una (Reserva Biológica do Município de Una; REBIO-Una), Bahia, Brazil.

\section{Material and Methods}

Four sampling campaigns were carried out at REBIO-Una in September 2011, April and August 2012, and January 2013. Specimens of Inga thibaudiana DC. (Fabaceae), Myrcia splendens (Sw.) DC. (Myrtaceae), and Pera glabrata (Schott) Baill. (Peraceae) were identified and marked in the field (five of each species). These species were chosen because they have socioeconomic and environmental importance. Leaf litter samples from the selected specimens were collected, labeled, stored in Kraft paper bags, and transported to the Laboratory of Fungal Diversity of the Cocoa Research Center (Centro de Pesquisas do Cacau CEPEC) in Ilhéus, Bahia. The samples were stored in pre-perforated plastic containers, gently washed in running water for one hour without disturbing the leaves, and then placed in a moist chamber. After 72 hours, the incubated material was observed under a stereomicroscope and monitored periodically for 30 days (Magalhães et al. 2011).

Slides used for observation under an optical microscope were prepared using fragments of hymenium content and ascomata sections prepared by freehand methods using razors and mounted in cotton blue mounting medium. Identification of fungal species was accomplished by consulting specialized literature. Photomicrographs were taken with a Sony Cyber-shot 16.2 megapixel digital camera. Dried specimens were deposited in the Mycological collection of the CEPEC herbarium.

\section{Results and Discussion}

Coccomyces leptosporus Speg., Anal. Soc. cient. argent. 19(6): 264 (1885).

Fig. 1a-e

Ascomata scattered in bleached spots bounded by a black line on the adaxial and abaxial leaf surfaces, $0.4-0.65 \mathrm{~mm}$ diam., Peridial wall brown, immersed in the substrate, becoming erumpent, opening by $3-4$ teeth, rounded to angular contour. Hymenium yellow on fresh or old material, remaining exposed when dry. Ascomata subepidermal to intra-epidermal; upper wall extending from the sides to join the lower wall, 18-65 $\mu \mathrm{m}$ thick, composed of dark brown cells. Paraphyses hyaline, filiform, 59-131 $\mu \mathrm{m}$ long, swollen apex, 
1.4-4 $\mu \mathrm{m}$ thick, forming an epithecium. Asci short-stalked, 94-126 × 3.4-5 $\mu \mathrm{m}$, cylindrical, thin-walled, 8-spored. Ascospores hyaline, filiform, 0 -septate, $40-86 \times 0.6-1 \mu \mathrm{m}$, without a prominent sheath.

Material examined: Una, 22.IX.2011, on decaying leaves of Inga thibaudiana, M.V.O. dos Santos 14 (CEPEC 2430); 02.IV.2012, on decaying leaves of $I$. thibaudiana, M.V.O. dos Santos 15 (CEPEC 2431); 26.VIII.2012, on decaying leaves of I. thibaudiana, M.V.O. dos Santos 16 (CEPEC 2432); 04.I.2013, on decaying leaves of I. thibaudiana, M.V.O. dos Santos 17 (CEPEC 2433).

The species occurs in South and Central America (Sherwood 1980), North America (Farr \& Rossman 2018), Austria (GBIF 2018).

The characters of the specimens presented in this study are typical of C. leptosporus, with some variations in the dimensions of the fungal structures.

The ascomata were slightly larger than those described by Sherwood (1980) $(0.3-0.5 \mathrm{~mm})$ but are
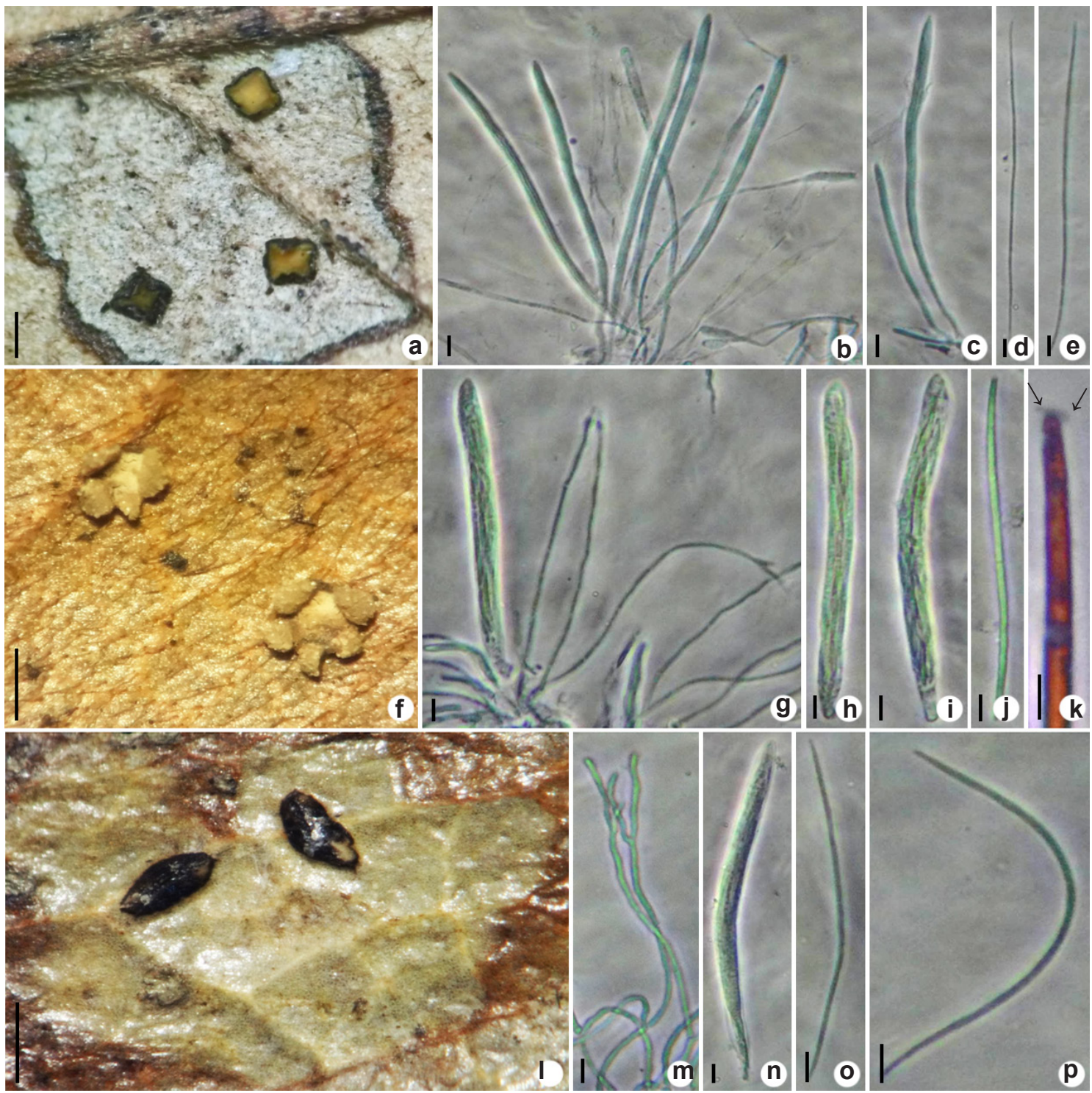

Figure 1 - a-e. Coccomyces leptosporus - a. ascomata; $\mathrm{b}$. asci and paraphyses; c. asci at different stages of development; d-e. ascospore. f-k. Marthamyces quadrifidus - f. ascomata; g. ascus and paraphyses; h-i. ascus; j-k. ascospore, detail of the gelatinous caps (k) indicated by arrows. 1-p. Terriera javanica - 1. ascomata; m. paraphyses; n. ascus; o,p. ascospore. Scale bars: $\mathrm{a}=0.5 \mathrm{~mm} ; \mathrm{b}, \mathrm{c}=8 \mu \mathrm{m} ; \mathrm{d}, \mathrm{e}, \mathrm{j}, \mathrm{k}=3 \mu \mathrm{m} ; \mathrm{f}, \mathrm{l}=0.3 \mathrm{~mm} ; \mathrm{g}, \mathrm{h}, \mathrm{i}, \mathrm{m}-\mathrm{p}=5 \mu \mathrm{m}$. 
consistent with the ranges reported by Hernández et al. (2014) (0.3-0.6 mm). The basal stroma was about $10 \mu \mathrm{m}$ thicker than the specimens reported by Sherwood (1980) and Hernández et al. (2014). The paraphyses showed length range broader than the values presented by Hernández et al. (2014) (100-105 $\mu \mathrm{m})$ and a narrower apex than reported by this author (2.5-3 $\mu \mathrm{m})$ and by Sherwood (1980) $(2.5-4 \mu \mathrm{m})$. The asci were larger and narrower than those found by Sherwood (1980) (90-105 × 5-6 $\mu \mathrm{m})$ and Hernández et al. (2014) (95-105 × 4-6 $\mu \mathrm{m})$. The ascospore dimensions were smaller than the values reported by Hernández et al. (2014) (98-100 $\mu \mathrm{m})$, with a minimum value closer to that established by Dennis (1970) (50-70 $\mu \mathrm{m})$.

Sherwood (1980) reported that $C$. leptosporus is a common taxon in tropical America and identified this ascomycete in the leaf litter of different plants, with most specimens likely derived from an unidentified plant species. Coccomyces leptosporus was previously identified in association with Inga spectabilis (Vahl) Willd. in Venezuela by Dennis (1970). However, this is the first record of this ascomycete from I. thibaudiana and in southern Bahia, Brazil.

Marthamyces quadrifidus (Lév.) Minter, Mycotaxon 87: 52 (2003). Fig. 1f-k

Ascomata, 0.15-0.5 mm diam., Subepidermal, not associated with bleaching of host tissue, or with zone lines, opening by prominent triangular flaps that fold back to expose the white to yellow cream pruinose hymenium; Lobes consisting of hyphal elements and cell remnants of the host, lower part embedded with white crystals; upper wall of the ascomata up to $38 \mu \mathrm{m}$ thick, composed of an undeveloped outer layer partially obscured by numerous crystals and formed by hyaline, cylindrical, cells, parallel to the surface of the host and by an inner layer composed of cylindrical, thin, hyaline, periphysoid-like elements, reaching up to $12 \mu \mathrm{m}$ long, observed close to the edge of the wall; poorly developed lower wall, numerous hyaline hyphae interspersed with hypodermic cells partially ruptured below the ascoma. Subhymenium sub-hyaline up to $9 \mu \mathrm{m}$ thick. Paraphyses, 0.6-2 $\mu \mathrm{m}$ in diam., with one or more branches, short and slightly narrowed near the apex. Asci, 56-115 ×4-8 $\mu \mathrm{m}$, cylindrical, often widest near the base, tapering gradually to the apex, wall undifferentiated at apex, 8-spored. Ascospores, 43-81 × 1-1.6 $\mu \mathrm{m}$, tapering slightly to each end, $0-1$-septate, apical and basal gelatinous caps.
Material examined: Una, 02.IV.2012, on decaying leaves of Myrcia splendens, M.V.O. dos Santos 19 (CEPEC 2435); 26.VIII.2012, on decaying leaves of M. splendens, M.V.O. dos Santos 20 (CEPEC 2436); 4.I.2013, on decaying leaves of M. splendens, M.V.O. dos Santos 21 (CEPEC 2437); 4.I.2013, on decaying leaves of Pera glabrata, M.V.O. dos Santos 22 (CEPEC 2438).

The species occurs in Tropical Asia, New Zealand, Australia, America (Johnston 2006), Morocco (El Kholfy et al. 2014) and French Polynesia (GBIF 2018).

The specimens found at REBIO-Una differ with respect to the size of structures reported in other descriptions. The ascomata sizes are smaller than those described by Sherwood (1977) (0.5-1 $\mathrm{mm}$ ) and Hernández et al. (2014) (0.4-1 mm); however, they are in agreement with the sizes described by Johnston (2006), [(0.2-)0.4-0.6 $\mathrm{mm}]$. The upper wall of the ascoma was narrower (50-65 $\mu \mathrm{m})$, and periphysoid-like elements were slightly larger than those found by Johnston (2006) (up to $10 \mu \mathrm{m}$ ). The width of the paraphyses was closer to the dimensions reported by Sherwood (1977) (1 m) and Hernández et al. (2014) (1-1.5 $\mu \mathrm{m})$; the paraphyses described by Johnston (2006) were slightly wider $(2-2.5 \mu \mathrm{m})$. A longer length of the asci was found in addition to the presence of smaller and narrower ascospores than reported by Sherwood (1977) $(70-100 \mu \mathrm{m} ; 65-80 \times 2 \mu \mathrm{m})$, Johnston (2006) [75-95(-100); 55-75 × 1.5-2 $\mu \mathrm{m}]$, and Hernández et al. (2014) (75-100 $\mu \mathrm{m} ; 60-80$ $\times 1.8-2 \mu \mathrm{m})$.

Marthamyces quadrifidus is distinguished from other species of the genus by the dehiscence of the ascoma, which is facilitated by structures resembling white, pruinose, prominent, and irregular lobules (Hernández et al. 2014).

Marthamyces quadrifidus is common and widespread in tropical Asia, America, and northern New Zealand and most likely occurs in a broad range of hosts, especially dicot substrates in northern Australia (Johnston 2006). The species has been reported in Northern Brazil (GBIF 2018), but this is the first record of the species in the Northeast region of Brazil and its association with M. splendens and $P$. glabrata.

Terriera javanica (Penz. and Sacc.) P.R. Johnst., Mycol. Pap. 176: 152 (2001).

Fig. 11-p

Ascomata, 0.2-0.5 mm, sub-epidermal, distributed as bleached spots, not surrounded by stromal lines, on the adaxial and abaxial foliar surfaces, oblong-elliptic to sublinear, ends \pm acute, 
wall black, unopened ascomata with narrow pale zone along future line of opening (single slot). Prismatic texture, hyaline to slightly brown, between the covering stroma and the basal stroma, having cells with 3.4-7.4 $\mu \mathrm{m}$ width. Sub hymenium 12-14.4 $\mu \mathrm{m}$ thick. Paraphyses filiform, swelling slightly to $1.2-2 \mu \mathrm{m}$ at apex, branching near the apex, forming compact epithecium above asci. Asci, 83-102 × 4-6 $\mu \mathrm{m}, \mathrm{J}-$, cylindrical, rounded apex with undifferentiated wall, 8 -spored, short basal stalk at maturity. Ascospores, $61-72 \times 0.6-1.4$ $\mu \mathrm{m}$, filiform, with guttules, 0 -septate, with subtruncated ends, mucilaginous sheath absent.

Material examined: Una, 2.IV.2012, on decaying leaves of Myrcia splendens, M.V.O. dos Santos 23 (CEPEC 2439); 26.VIII.2012, on decaying leaves of M. splendens, M.V.O. dos Santos 24 (CEPEC 2440); 4.I.2013, on decaying leaves of M. splendens, M.V.O. dos Santos 25 (CEPEC 2441).

The species occurs in Indonesia (Johnston 2001), Brazil (this paper).

Terriera javanica and T. javanica var. pandani were synonymized, and the specimens found in the Una Biological Reserve have characteristics of both taxa. However, the specimens show greater similarity to the description reported for T. javanica var. pandani.

Some differences in dimensions were observed between the specimens found in $M$. splendens leaf litter and the description of Johnston (2001). The ascomata were smaller $(0.4-1.5 \mathrm{~mm})$, and the asci $(85-95 \times 5.5-7 \mu \mathrm{m})$ and ascospores $(50-60 \times 1.5 \mu \mathrm{m})$ were larger and slightly narrower. Narrower paraphyses $(2.5-5 \mu \mathrm{m})$ were also observed.

Terriera javanica is microscopically very similar to T. sacchari (Lyon) P.R. Johnst. However, the paraphyses are rarely branched in T. sacchari. Terriera javanica was recorded in Pandanus Stickman (Pandanaceae) and Elettaria Maton (Zingiberaceae) leaf litter (Johnston 2001). This is the first record of T. javanica in the Americas and of the occurrence of this taxon on M. splendens leaf litter.

\section{Acknowledgements}

Thanks are due to: the Coordenação de Aperfeiçoamento de Pessoal de Nível Superior (CAPES) for grants awarded to the first and the last author; the Conselho Nacional de Desenvolvimento Científico e Tecnológico (CNPq) for a grant awarded to Dr. Edna Dora M. N. Luz; the Programa de Pós-Graduação em Biologia de Fungos (PPGBF) of the Universidade Federal de Pernambuco (UFPE). Gratitude also is expressed to the ICMBio and the REBIO-Una; to José Lima da Paixão for his assistance during the sampling time and the to the Cacao Research Center of the Comissão Executiva do Plano da Lavoura Cacaueira (CEPLAC) for providing the laboratory and facilities to conduct the research.

\section{References}

Chen J, Lin Y, Hou C \& Wang S (2011) Species of Rhytismataceae on Camellia spp. from the Chinese mainland. Mycotaxon 118: 219-230.

Dennis RWG (1970) Fungus flora of Venezuela and adjacent countries. H.M.S.O, London. 531p.

El Kholfy S, Outcoumit A, Touhami AO, Belahbib N, Benkirane R \& Douira A (2014) Bibliographic inventory of Tangier's fungi: catalogue of the Ascomycetes fungal flora. International Journal of Plant, Animal and Environmental Sciences 4: 77-92.

Farr DF \& Rossman AY (2018) Fungal databases. U.S. National Fungus Collections, ARS, USDA. Disponível em <https://nt.ars-grin.gov/ fungaldatabases/ $>$. Acesso em 5 janeiro 2018.

GBIF (2018) Free and open access to biodiversity data. Disponível em <https://www.gbif.org/occurrence/ search?q=>. Acesso em 5 janeiro 2018.

Hernández MC, Johnston PR \& Minter DW (2014) Rhytismataceae (Ascomycota) in Cuba. Willdenowia 44: 65-75.

Hou C \& Piepenbring M (2009) New species and new records of Rhytismatales from Panama. Mycologia 101: 565-572.

Johnston PR (2001) Monograph of the monocotyledoninhabiting species of Lophodermium. Mycological Papers 176: 1-239.

Johnston PR (2006) Rhytismatales of Australia: the genus Marthamyces. Australian Systematic Botany 19: 135-146.

Johnston PR \& Park D (2007) Revision of the species of Rhytismataceae reported by Spegazzini from South America. Boletín de la Sociedad Argentina de Botánica 42: 87-105.

Kirk PM, Cannon PF, Minter DW \& Stalpers JA (2008) Dictionary of the Fungi. $10^{\mathrm{a}}$ ed. CAB International, Wallingford. 771p.

Lantz H, Johnston PR, Park D \& Minter DW (2011) Molecular phylogeny reveals a core clade of Rhytismatales. Mycologia 103: 57-74.

Li Z, Cao N, Chen H, Taylor JE \& Hou C (2014) New species and new records of Rhytismataceae from Japan. Mycological Progress 13: 951-958.

Magalhães DMA, Luz EDMN, Magalhães AF, Santos Filho LP, Loguercio LL \& Bezerra JL (2011) Riqueza de fungos anamorfos na serapilheira de Manilkara maxima, Parinari alvimii e Harleyodendron 
unifoliolatum na Mata Atlântica do Sul da Bahia. Acta Botanica Brasilica 25: 899-907.

Minter DW (2003) Propolis and Marthamyces gen. nov. (Rhytismatales). Mycotaxon 87: 43-52.

Sherwood MA (1977) Taxonomic studies in the Phacidiales: Propolis and Propolomyces. Mycotaxon 5: 320-330.

Sherwood MA (1980) Taxonomic studies in the Phacidiales: the genus Coccomyces
(Rhytismataceae). Occasional Papers of the Farlow Herbarium of Cryptogamic Botany 15: 1-120.

Spegazzini C (1885) Fungi guaranitici. Pugillus I. Anales de la Sociedad Científica Argentina 19: 241-265.

Zheng Q, Lin Y, Yu S \& Chen L (2011) Species of Rhytismataceae on Lithocarpus spp. from $\mathrm{Mt}$ Huangshan, China. Mycotaxon 118: 311-323. 